\title{
Oral condition of institutionalized older people: influence on anthropometric indicators, food and nutrient intake
}

\section{Condición oral de las personas mayores institucionalizadas: influencia en los indicadores antropométricos y la ingesta de alimentos y nutrientes}

\footnotetext{
Lilian Fernanda Galesi-Pacheco ${ }^{1}$. https://orcid.org/0000-0002-6453-0356 Vania Aparecida Leandro-Merhi2 ${ }^{*}$. https://orcid.org/0000-0002-2623-6471

Gabriela Marchiori Carmo Azzolin ${ }^{3}$. https://orcid.org/0000-0003-1888-7597 Maria Rita Marques de Oliveira ${ }^{4}$. https://orcid.org/0000-0003-1226-4364
}

1. Institute of Biosciences, Letters and Exact Sciences, São Paulo State University (UNESP), São José do Rio Preto, SP, Brazil. 2. Posgraduate Program in Health Sciences and of the School of Nutrition, PUC-Campinas-SP-Brazil. 3. School of Nursing, PUC-Campinas-SP-Brazil. 4. Institute of Biosciences, São Paulo State University (UNESP), Botucatu, SP, Brazil.

Corresponding author: Vânia Aparecida Leandro-Merhi, Av. John Boyd Dunlop, s/n, Jardim Ipaussurama, Campinas, Cep:13034-685. SP - Brazil. Email: vapaleme@gmail.com

\begin{abstract}
Objective: To assess whether there are differences between oral problems and food, energy, and nutrient intake and anthropometric indicators of institutionalized older adults. Methods: A total of 150 older people participated in the study. Their nutritional status was determined by anthropometric indicators and food intake. Oral problems were examined by a trained dentist who checked for caries, periodontitis, dry mouth, edentulism, and poorly-fitting partial or complete dentures. The categorical variables were analyzed by the Fisher's Exact Test and the continuous variables were analyzed by the Student's $t$-test for parametric data and the Mann-Whitney test for nonparametric data ( $p \leq 0.05)$. Results: Older people with oral problems presented lower anthropometric measurements and indices except for biceps skinfold thickness and consumed less energy $(p=0.027)$, protein $(p=0.012)$, lipids (0.012), and pan-fried meats $(p=0.001)$. Conclusion: Anthropometric indicators and the energy, protein and lipid intake were lower in elderly people with oral problems. This work warns about the importance of oral health for the good nutrition of older people and the need to establish strategies to adapt the diet of this population.
\end{abstract}

Keywords: Anthropometry; Food intake; Nutritional status; Older people nutrition; Oral health.

\section{RESUMEN}

Objetivo: Evaluar si existe una diferencia entre los problemas orales y la ingesta de alimentos, energía y nutrientes e indicadores antropométricos de adultos mayores institucionalizados. Métodos: Un total de 150 personas mayores participaron en el estudio. Su estado nutricional se determinó mediante indicadores antropométricos y la ingesta de alimentos. Los problemas orales fueron examinados por un dentista capacitado que verificó la presencia de caries, periodontitis, boca seca, edentulismo y dentaduras postizas parciales o completas mal ajustadas. Las variables categóricas se evaluaron mediante la 
Prueba Exacta de Fisher y las variables continuas se evaluaron mediante la prueba $t$ de Student para datos paramétricos y la prueba de Mann-Whitney para datos no paramétricos $(p \leq 0.05)$. Resultados: Las personas mayores con problemas orales presentaron mediciones e índices antropométricos más bajos, excepto el grosor del pliegue cutáneo del bíceps y consumieron menos energía $(p=0.027)$, proteínas $(p=0.012)$, lípidos $(0.012)$ y carnes fritas $(p=0.001)$. Conclusión: Los indicadores antropométricos y el consumo de energía, proteínas y lípidos fueron menores en personas mayores con problemas bucales. Este trabajo advierte sobre la importancia de la salud oral para la buena nutrición de las personas mayores y la necesidad de establecer estrategias para adaptar la dieta de esta población.

Palabras clave: Antropometría; Estado nutricional; Nutrición de personas mayores; La ingesta de alimentos; Salud bucal.

\section{INTRODUCTION}

Old age imposes physical disabilities, affective absences, and other limitations inherent to this life phase. Many health problems affect older individuals, such as cardiovascular diseases, dementia, depression, and natural age-related changes, acting especially on the digestive and musculoskeletal systems. Furthermore, older people often suffer from poverty, social isolation, and loss of autonomy to carry out their activities of daily living. However, physical and emotional adaptations are also inherent to the ageing process. They may give individuals a subjective sense of wellbeing and help them to develop physical autonomy and other mechanisms to compensate their limitations, always dependent on the degree of personal resilience ${ }^{2}$.

Loss of oral health is one of the problems that affect older people. Poor oral health and dental problems are associated with the risk of malnutrition in institutionalized elderly people? Since chewing is the initial step of the digestive process, oral problems, common in older people, play an important role in nutrition and quality of life, and may also contribute to the development of diseases and increase mortality ${ }^{4}$. The main oral problems that impair chewing are numerous caries, periodontal infections, missing teeth, dry mouth, and poorlyfitting partial or complete dentures, which reduce mastication efficiency $y^{3,5}$. Poor oral health was also associated with the reduction of food consumption and the poor intake of nutrients among elderly Japanese; and this association has shown the relationship between elderly people oral health and their nutrition and health ${ }^{6}$.

The intake of essential nutrients usually requires the presence of healthy natural teeth or well-adjusted dentures 5 . Hence, foods must be prepared taking into consideration chewing and deglutition limitations to prevent nutritional deficiencies. Despite the evidence that poor oral condition is responsible for low food intake and consequently, poor nutritional status, the studies that investigate this relationship present contradictory results because they use different methods and/or methods that are not very accurate for this age group ${ }^{7,8,9,10}$. Some studies suggest that older individuals with compromised oral health adapt their diet and consequently, obtain as much nutrients as everyone else ${ }^{8}$.

Other recent studies have also pointed out the importance of oral health research, fragility, masticatory function and food consumption among elderly people, which could also contribute to the reduction of morbidity and mortality rates in this group, in particular ${ }^{11,12}$. In order to clarify this discrepancy and settle this issue reliably, this study proposed to study it under controlled conditions. Hence, the objective of this study was to verify whether there are differences between oral problems and food, energy, and nutrient intakes of institutionalized older adults.

\section{METHODS \\ Cases}

A total of 150 males and females aged 60 years or more living in a long-stay institution (LSI) located in the eastern region of São Paulo state, Brazil, participated in the study. The only exclusion criteria were age below 60 years or partial or complete use of enteral or parenteral nutrition.

The sample was selected by stratified sampling. The sample size was calculated as recommended by Cochran ${ }^{13}$ taking into account a population of 238 institutionalized individuals divided into five sectors, assuming $\alpha=0.05$. The calculation was based on an earlier study at the same institution, which found a prevalence of malnutrition of $20 \%$ using the Mini Nutritional Assessment (MNA $)^{14}$. The MNA was used exclusively for calculating sample size, resulting in 150 individuals recruited randomly in the different sectors. The individuals who refused to participate in the study were replaced by other individuals chosen randomly until the necessary sample size was reached.

All participants signed an informed consent form. A social assistant signed for those who could not sign the form after obtaining written authorization from their families. The conditions that did not allow participants to sign the consent form were dementia, visual problems or lack of manual dexterity to sign. This study was approved by the Ethical Committee in Research at the Methodist University of Piracicaba-SP-Brazil (protocol number 83/05).

The research is part of the doctoral thesis from the first author, who carried out all the evaluations, except for the analysis of the oral condition conducted by the dentist of the institution.

\section{Food intake assessment}

Food intake was assessed by weighing and recording the foods consumed on three days of different weeks at approximately one-week intervals. A weekend day was not included because the food served on those days did not differ from that served on the other days. Before the meals were distributed, the foods were weighed using the utensils used by the institution. Next, the amount served to each person was recorded in cooking units. After the meal, the consumed fractions were again recorded in cooking units 
and later converted into grams. Energy, protein, carbohydrate, lipid, iron, vitamin $\mathrm{C}$, and fiber intakes were calculated by the nutritional assessment software Avanutri, version 3.1.1, produced by Avanutri Informática Ltda ${ }^{15}$.

To assess food intake and investigate the association between food consistency and oral problems, we counted the number of daily servings consumed of the following foods: stew, pan-fried meat, beans, milk, bread, soft salty preparations, soft sweet preparations, rice, polenta, fruits, raw vegetables, and cooked vegetables. Then we calculated the mean number of servings of each food in the three study days. Serving sizes were defined by Philippi et $\mathrm{al}^{16}$. Participants were divided into two groups regarding their energy and protein intakes, one group above the intake median and one group below the intake median.

\section{Oral health assessment}

The oral problems were examined by a trained dentist who checked for caries, periodontitis, dry mouth, edentulism, and poorly-fitting partial or complete dentures. Individuals with sixteen teeth or fewer who did not wear partial or complete dentures were considered edentulous. These problems were chosen because of how they affect chewing and the initial formation of the food bolus. Because of the low prevalence of oral problems, participants were divided into two groups, one without oral problems named "healthy mouth" and one with oral problems named "unhealthy mouth." In order to be included in the "unhealthy mouth" group, the elderly had to present at least one of the 5 oral disorders surveyed.

\section{Nutritional status indicators}

The following nutritional status indicators were measured and calculated: body weight; body height; body mass index (BMI); mid-upper arm (MUAC) and calf (CC) circumferences; triceps (TST), biceps (BST), subscapular (SSST), and suprailiac (SST) skinfold thicknesses; and percentage of body fat (\%BF). MUAC and TST were used for calculating mid-arm muscle circumference (MAMC) and mid-arm fat area (MAFA).

The circumferences were measured by an inelastic tape measure with an accuracy of one millimeter. The skinfold thicknesses were measured by a caliper (LANGE CALIPER, Cambridge Scientific, USA). The measurements were taken as recommended by Lohman et a $1^{17}$.

The height of those who could not stand was measured in the supine position by measuring the distance between the top of the head and the sole of the foot. When this measurement was not possible, we measured knee height and calculated body height as recommended by Chumlea et $\mathrm{al}^{18}$. The patients who could stand were measured by a portable stadiometer. Weight was measured by a portable electronic scale with capacity of $150 \mathrm{~kg}$ and accuracy of $100 \mathrm{~g}$. Patients who could not stand were weighed on their wheelchairs by an electronic platform scale with capacity of $300 \mathrm{~kg}$ attached to a wooden ramp. The weight of the wheelchair was then deducted from the total weight.

Anthropometric indicators were analyzed according to oral problems and energy and protein intake. For protein and energy analysis, the participants were divided into two groups using the mean as a cut-off point. Subsequently, the anthropometric indicators were compared according to the groups above and below the median for protein and energy intake.

\section{Other Assessments}

In the studied population, screening tests were applied to support the characterization of the group of elderly participants in the investigation. The Mini-Mental State Examination (MMSE) ${ }^{19}$ was used as an instrument for screening the presence of dementia in the studied group. Questions evaluate orientation, attention, memory, language, apraxia, and ability to respond to simple commands. In order to become knowledgeable of the autonomy for daily living activities, the Activities of daily living - $\mathrm{ADL}^{20}$ method was used. Its assessment involves four activities required for adult independence: mobility, incontinence, feeding and personal hygiene. To investigate signs of depression, we used the questions of the Brazil Old Age Schedule - BOAS ${ }^{21}$ questionnaire, which verifies the presence of the following variables: loneliness, sadness, discomfort, pessimism about the future, irritation, self-blame, suicidal thoughts, headache, dissatisfaction, sleep and appetite disorders.

In this study, cutoff points were not used for classification, but only the total score according to the presence of oral disorders in order to compare the groups and characterize the profile of the elderly patients.

\section{Statistical analysis}

The statistical analyses were performed by the software Bioestat version 3.022. The software Statistical Analysis Software (SAS) tested data normality ${ }^{23}$. The categorical variables were analyzed using the Fisher's Exact Test and continuous variables were analyzed using the Student's t-test for parametric data and the Mann-Whitney test for nonparametric data. The significance level was set at $5 \%(p \leq 0.05)$.

\section{RESULTS}

The mean age and standard deviation (SD) of the 150 participants was $77 \pm 10$ years; $52 \%$ were females with a mean age of $80 \pm 9$ years. The males had a mean age of $73 \pm 10$ years.

In the comparison between the analysis groups (Table 1), there were no differences in age, time at institution, ADL score (Activities of Daily Living-score) and depression, sex, presence of caregiver and use of wheelchairs. A difference was found in the MMSE score (The Mini Mental State Examination-score), however, energy consumption was not associated with this variable (<score: - $1807 \pm 552$; >score: $-1823 \pm 485, p=0.850$ Student's t-test).

The most prevalent oral health problem was edentulism $(46 \%)$, followed by periodontitis $(11.5 \%)$, poorly-fitting dentures $(10 \%)$, caries $(8.7 \%)$, and dry mouth ( $4.7 \%)$. All poorly-fitting dentures were loose. No denture was making too much or too little pressure in the oral cavity.

Poorly-fitting dentures and dry mouth were more prevalent in older individuals $(p=0.001)$ with mean ages of $86.4 \pm 9.4$ 
and $83.9 \pm 11.5$, respectively. On the other hand, participants with caries ( $73.9 \pm 10.2$ years), periodontitis ( $70.6 \pm 9.9$ years), edentulism $(76.9 \pm 10.5$ years), and without oral problems ( $76.9 \pm 10.8$ years) tended to have lower mean ages.

Participants with oral problems consumed less energy $(p=0.027)$, proteins $(p=0.012)$, and lipids $(p=0.012)$ (Table 2 ). The groups did not differ regarding their intake of carbohydrates, iron, vitamin C, and fiber. Participants with oral problems also had significantly lower anthropometric measurements and indices, except for BST (Table 3).

Participant BMI also showed a disproportionate prevalence of underweight individuals $(\mathrm{BMl}<22 \mathrm{~kg} / \mathrm{m} 2)^{24}$ in the two groups: $42.7 \%$ in the "unhealthy mouth" group and $24.1 \%$ in the "healthy mouth" group. Table 4 shows that participants who consumed less energy and protein than the median intakes had lower anthropometric measurements and indices, except for TST for energy intake, which did not exhibit a statistically significant difference.

The healthy and unhealthy oral status groups differed significantly with respect to pan-fried meat intake $(p=0.001)$, one of the study foods with the hardest texture and most challenging to chew (Figure 1).

The other meats were stew, slow-cooked meat, hotdogs, pork cooked with beans, and soup with beef and chicken. The soft salty preparations included mashed potatoes, thick soup with noodles, creamy cassava soup, and polenta. The soft sweet preparations included porridge, pudding, custard, bread porridge, and cookie porridge. The fruits included banana, papaya, and mandarin orange, and sometimes pineapple.

Table 1. General characteristics of the study population.

\begin{tabular}{|c|c|c|c|}
\hline & $\begin{array}{c}\text { Healthy mouth } \\
\text { Median (min-max) }\end{array}$ & $\begin{array}{l}\text { Unhealthy mouth } \\
\text { Median (min-max) }\end{array}$ & p-value* \\
\hline Age (years) & $75.5(60-93)$ & $75(60-100)$ & 0.861 \\
\hline Time of institutionalization (years) & $2.2(0.1-31.6)$ & $3.2(0.1-38.0)$ & 0.121 \\
\hline Score ADL & $7(5-18)$ & $8(5-18)$ & 0.197 \\
\hline Score MMSE & $22(0-30)$ & $16(0-30)$ & $<0.001$ \\
\hline \multirow[t]{2}{*}{ Depression } & $2(0-11)$ & $1(0-15)$ & 0.653 \\
\hline & n (\%) & n (\%) & \\
\hline Sex & & & $\mathrm{p}^{* *}$ \\
\hline Female & $30(20)$ & $48(32)$ & 0.315 \\
\hline Male & $24(16)$ & $48(32)$ & \\
\hline \multicolumn{4}{|l|}{ Presence of caregiver } \\
\hline Yes & $6(4)$ & $10(6,5)$ & 0.549 \\
\hline No & $48(32)$ & $86(57,5)$ & \\
\hline \multicolumn{4}{|l|}{ Wheelchair } \\
\hline Yes & $10(6,5)$ & $32(21,5)$ & 0.985 \\
\hline No & $44(29,5)$ & $64(42,5)$ & \\
\hline
\end{tabular}

$\mathrm{p}^{*}=$ Mann Whitney Test; $\mathrm{p}^{* *}=$ Fisher's Exact Test

Score ADL= Activities of Daily Living : Sum of all categories (to perform meal, to dress up, to take care of the appearance, to move, to get up, to take bath, to go to the bathroom) - minimum score 0 and maximum 21 (higher number indicates greater dependency).

Score MMSE= The Mini Mental State Examination: Ranging from 0 to 30.

Depression score: higher scores indicate higher depression risk, ranging from 0 to 26. 
Table 2. Energy and nutrient intakes according to oral health.

\begin{tabular}{|lccc|}
\hline Indicator & $\begin{array}{c}\text { Healthy mouth } \\
\text { Mean } \pm \text { SD }\end{array}$ & $\begin{array}{c}\text { Unhealthy mouth } \\
\text { Mean } \pm \text { SD }\end{array}$ & P-value \\
\hline Energy (kcal) & $1926 \pm 558$ & $1755 \pm 495$ & 0.027 \\
Proteins (g) & $61.1 \pm 19.4$ & $53 \pm 18.1$ & 0.012 \\
Carbohydrates (g) & $292.3 \pm 80.5$ & $279.0 \pm 81.6$ & 0.337 \\
Fats (g) & $56.9 \pm 23.5$ & $47.6 \pm 17.3$ & 0.012 \\
Iron (mg) & $8.9 \pm 3.4$ & $10.7 \pm 16.6$ & 0.289 \\
Vitamin C (mg) & $49.1 \pm 30.7$ & $45.2 \pm 23.5$ & 0.417 \\
Fiber (g) & $13.6 \pm 5.9$ & $12.7 \pm 3.7$ & 0.314 \\
Total (n) & 54 & 96 & 150 \\
\hline
\end{tabular}

$\mathrm{p}=$ Student's t-test.

Table 3. Anthropometric indicators according to oral health.

\begin{tabular}{|c|c|c|c|}
\hline Indicator & $\begin{array}{l}\text { Healthy mouth } \\
\text { Mean } \pm \text { SD }\end{array}$ & $\begin{array}{c}\text { Unhealthy mouth } \\
\text { Mean } \pm \text { SD }\end{array}$ & P-value \\
\hline MUAC (cm) & $29.4 \pm 4.7$ & $27.5 \pm 4.3$ & 0.009 \\
\hline MAMC $(\mathrm{cm})$ & $23.8 \pm 4.8$ & $22.9 \pm 3.9$ & 0.039 \\
\hline TST (mm) & $16.2 \pm 7.6$ & $14.1 \pm 7.3$ & 0.046 \\
\hline BST (mm) & $9.7 \pm 5.5$ & $8.8 \pm 5.3$ & 0.174 \\
\hline $\mathrm{SST}(\mathrm{mm})$ & $19.6 \pm 10.1$ & $15.7 \pm 8.2$ & 0.008 \\
\hline $\mathrm{SSST}(\mathrm{mm})$ & $18.3 \pm 7.5$ & $15.7 \pm 7.7$ & 0.025 \\
\hline
\end{tabular}

BMI: body mass index; MUAC: mid-upper arm circumference; MAMC: mid-arm muscle circumference; MAFA: mid-arm fat area; CC: calf circumference; TST: triceps skinfold thickness; BST: biceps skinfold thickness; SST: suprailiac skinfold thickness; SSST: subscapular skinfold thickness; $\%$ BF: percentage of body fat. $\mathrm{p}=$ Student's t-test.

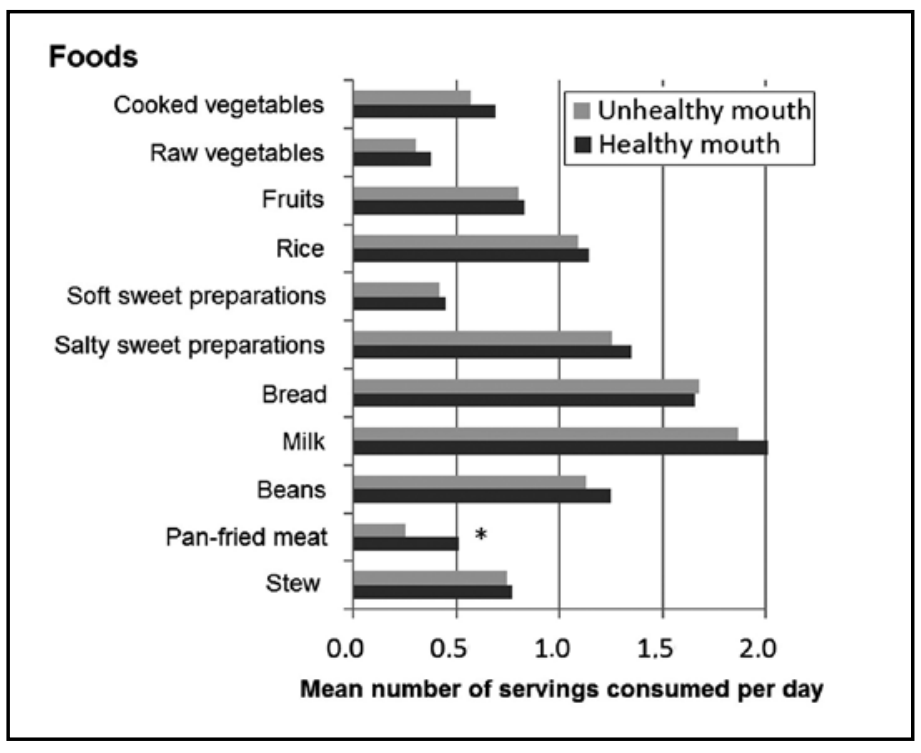

Figure 1: Number of food servings consumed by older people according to oral health. 
Table 4. Anthropometric indicators according to energy and protein intake of the sample.

\begin{tabular}{|c|c|c|c|c|c|c|}
\hline \multirow[b]{2}{*}{ Indicator } & \multicolumn{2}{|c|}{ ENERGY } & \multicolumn{4}{|c|}{ PROTEIN } \\
\hline & $\begin{array}{c}<\text { median } \\
\text { Mean } \pm \text { SD }\end{array}$ & $\begin{array}{l}>\text { median } \\
\text { Mean } \pm \text { SD }\end{array}$ & $p$-value & $\begin{array}{l}<\text { median } \\
\text { Mean } \pm \text { SD }\end{array}$ & $\begin{array}{l}>\text { median } \\
\text { Mean } \pm \text { SD }\end{array}$ & $p$-value \\
\hline $\mathrm{BMI}\left(\mathrm{kg} / \mathrm{m}^{2}\right)$ & $22.4 \pm 5.3$ & $25.6 \pm 5.2$ & $<0.001$ & $22.2 \pm 5.1$ & $25.8 \pm 5.3$ & $<0.001$ \\
\hline MUAC (cm) & $26.8 \pm 4.4$ & $29.6 \pm 4.2$ & $<0.001$ & $26.9 \pm 4.3$ & $29.5 \pm 4.4$ & $<0.001$ \\
\hline MAMC $(\mathrm{cm})$ & $21.8 \pm 4.8$ & $24.6 \pm 3.1$ & $<0.001$ & $22.4 \pm 4.2$ & $24.1 \pm 4.2$ & 0.008 \\
\hline $\operatorname{MAFA}\left(\mathrm{cm}^{2}\right)$ & $13.7 \pm 7.9$ & $17.1 \pm 8.2$ & 0.003 & $13.4 \pm 7.6$ & $17.5 \pm 8.3$ & 0.001 \\
\hline $\mathrm{CC}(\mathrm{cm})$ & $30.6 \pm 3.9$ & $33.9 \pm 4.2$ & $<0.001$ & $30.6 \pm 3.8$ & $34.0 \pm 4.3$ & $<0.001$ \\
\hline $\mathrm{TST}(\mathrm{mm})$ & $14.0 \pm 7.1$ & $15.7 \pm 7.6$ & 0.0865 & $13.3 \pm 7.1$ & $16.4 \pm 7.4$ & 0.006 \\
\hline BST (mm) & $8.4 \pm 4.7$ & $10.7 \pm 6.0$ & 0.009 & $7.6 \pm 4.6$ & $11.5 \pm 5.6$ & $<0.001$ \\
\hline $\mathrm{SST}(\mathrm{mm})$ & $15.1 \pm 8.5$ & $19.0 \pm 9.1$ & 0.005 & $14.5 \pm 8.1$ & $19.6 \pm 9.1$ & $<0.001$ \\
\hline SSST (mm) & $14.5 \pm 6.9$ & $18.7 \pm 7.8$ & $<0.001$ & $14.4 \pm 7.1$ & $18.8 \pm 7.6$ & $<0.001$ \\
\hline$\% \mathrm{BF}$ & $28.9 \pm 9.2$ & $31.7 \pm 8.4$ & 0.032 & $27.7 \pm 9.2$ & $32.9 \pm 7.8$ & $<0.001$ \\
\hline
\end{tabular}

BMI: body mass index; MUAC: mid-upper arm circumference; MAMC: mid-arm muscle circumference; MAFA: mid-arm fat area; CC: calf circumference; TST: triceps skinfold thickness; BST: biceps skinfold thickness; SST: suprailiac skinfold thickness; SSST: subscapular skinfold thickness; \%BF: percentage of body fat. $p=$ Student's t-test.

\section{DISCUSSION}

This study found that oral problems are associated with lower energy, protein, and lipid intakes under controlled conditions and consequently, with lower anthropometric indicators of nutritional status. Some studies did not find a relationship between oral problems and indicators of nutritional status ${ }^{7,25}$. In this study all anthropometric indicators of nutritional status except for BST were associated with oral problems.

The study was careful to use various anthropometric indicators of nutritional status that contemplate different aspects of body composition, such as indicators of muscle mass (MAMC, CC), fat mass (skinfold thicknesses, \%BF, and MAFA), or mixed (BMI, MUAC). Moreover, to increase data reliability, we chose to measure the indicators directly instead of using equations. Equations were only used when the direct measurement was not possible. The use of equations for estimating body measurements in different races and ethnicities could compromise the accuracy of the results ${ }^{26}$.

Kossioni et al ${ }^{7}$ and Andrade et $\mathrm{al}^{8}$ did not find a relationship between $\mathrm{BMI}$ and number of teeth or dental condition. Their findings were corroborated by Rodrigues Junior et $\mathrm{a}^{25}$, who did not find associations between missing teeth and BMI, body circumferences, percentage of body fat, and skinfold thicknesses; only SST was associated with BMI. On the other hand, Marcenes et $\mathrm{a}^{27}$ found that edentulous older people have a higher prevalence of underweight (12.3\%) than people with eleven or more teeth (2.9\%). Likewise, a Japanese study that investigated the relationships between chewing ability and anthropometric measurements in older people found that body weight and MUAC were associated with chewing ability, and BMI was identified as one of the predictors of chewing ability in a regression model ${ }^{4}$.

As the results of this study evidence the relationships between oral health, food intake, and nutritional status, we question which adaptive processes affect nutritional status. Older people living in institutions with few food choices compensate their eating difficulties by avoiding certain foods or eating less, but these strategies are not without consequences: older people with oral problems have lower energy and protein intakes, which may have contributed to their different nutritional status.

Given the characteristics of the foods consumed, it is likely that proteins and lipids came from meats, consumed differently by the study groups. Additionally, the highcarbohydrate foods offered by the institution, such as mashes, porridges, and creamy soups, were softer and thereby consumed by everyone. This may explain why the carbohydrate intake of the groups with and without oral problems did not differ.

This study found a relationship between oral health and macronutrient intake but not between oral health and micronutrient intake, contrary to Okada ${ }^{4}$. The absence of relationship between oral health and micronutrient intake is probably explained by the same reason that explained carbohydrate intake: micronutrients were mostly present in soft foods, consumed by everyone. Like lipids and proteins, iron may have come from meats, but after analyzing the 
menu, it may also have come from beans. In Brazil, beans are consumed with broth, making them soft and facilitating their ingestion. Vitamin $\mathrm{C}$ may have come from mandarin orange, also easily consumed.

The absence of a significant difference between foods of different textures is probably due to the soft foods, such as soft sweet and salty preparations and cooked vegetables, offered to everyone. Hence, even those who could consume harder foods ended up consuming softer foods, since that was how the foods were prepared. The fruits listed in the food diaries are an example. The most frequent and consumed fruits were papaya, banana, and mandarin orange, all easy to consume.

The same did not occur with meat intake because when pan-fried meats were served, softer meats were also served, such as shredded chicken. This explains the significant difference in the consumption of pan-fried meats by the two oral-status groups. However, the availability of a softer meat did not imply that both groups consumed the same amount of food.

If the study had been conducted at an institution with many foods of different textures, it might have been possible to determine whether people with oral problems prefer softer foods. Hence, proper external conditions are necessary for people to make adequate adaptations. Kossioni et al ${ }^{7}$ found that oral problems and chewing difficulties in older people were not associated with the intake frequency of hard foods, such as meat, vegetables, and fruits; however, they were associated with more frequent intake of soft foods, such as shredded meats, boiled chicken, cooked vegetables, bread, pasta, rice, and soft fruits, such as orange, melon, and grape. On the other hand, Marcenes et al. ${ }^{27}$ found that most institutionalized edentulous older people reported eating difficulties and inability to eat apple, raw carrot, well-done steak, and nuts, and like the present study, they probably did not have a wide variety of foods to choose from.

The fiber intake of the two groups was extremely low, much below recommendations, indicating a low intake of fruits, vegetables, and whole grains. The low intake of fruits and vegetables can be explained by the type of institution. The institution is a philanthropic entity, common in Brazil, depending mostly on donations. Thus, it is possible that it could not provide adequate access to all food groups throughout the year. The participants would probably consume more such foods if they were served more frequently.

The study sample represents the demographic profile of institutionalized Brazilian older people, with a prevalence of females with higher mean age ${ }^{28,29}$. According to the last census conducted in 2010 by the Brazilian Institute of Geography and Statistics (IBGE), the Brazilian life expectancy was 73.4 years, very close to the mean age of the study men $(73 \pm 10$ years), but lower than the mean age of the study women $(80 \pm 9 \text { years })^{30}$. This profile is expected in long-stay Brazilian institutions like the one studied, which generally house older individuals with low socioeconomic level who need help with activities of daily living. In addition to the fact that women live longer, this age difference between men and women probably stems from the fact that women in unfavorable socioeconomic conditions are more likely to become ill, disabled, or widowed, predisposing them to institutionalization ${ }^{28}$.

Edentulism was the most prevalent (46\%) oral problem in the study population. According to Emami et $\mathrm{a}^{31}$, this condition is strongly associated with socioeconomic factors and more prevalent in women. In developed countries like the United States and Canada, the prevalence of edentulism in older individuals is $25 \%$ and $21.7 \%$, respectively ${ }^{31,32}$.

A recent study ${ }^{33}$ that investigated the oral health of older people has shown that it represents a lifelong investment for this population and that health policies should consider this type of care in the elderly. Other studies also point out the urgent need for further research in the field of oral health and geriatric dentistry ${ }^{34}$. And a study developed among Brazilian elderly people ${ }^{35}$, which evaluated the relationship between daily life activities and oral health status, showed that functional dependence in daily live activities has implications for the oral health status of this group. Moreover, older people with physical and cognitive disabilities or depression, common conditions in institutions, are more likely to be edentulous and not have dentures ${ }^{4}$.

Poorly-fitting dentures may be explained by the lack of adjustments made over the years. In addition to the constant changing nature of oral tissues, dentures deteriorate and their age can significantly impact their retention and stability ${ }^{36,37}$. This is one more care that should be provided to older people to improve their quality of life. Dry mouth, also found among the study participants, may be caused by isolated pharmaceuticals, such as antidepressants, antihistamines, and anticholinergic drugs, but are especially caused by a combination of pharmaceuticals as the number of pharmaceuticals taken daily increases with age ${ }^{37}$. Although it is not possible to act on the cause of the problem, this side effect deserves attention from health professionals.

One limitation of this study was the lack of detailed and refined evaluation in the classification of xerostomia, the level of cavities and periodontal disease and edentulism. The long-stay institution relied on the volunteer work of a dentist who clinically assessed the presence of oral problems. Only two categories were considered for the number of teeth present (greater than or less than 16 teeth) and the existence of occlusal pairs was not considered, nor was the level of cavities and periodontal disease (only if they were present). The salivary flow or the application of an oral perception questionnaire were also not measured, as performed in the study by Mesas et $\mathrm{al}^{38}$.

The high prevalence of dementia (48\%) in this group prevented asking them directly ${ }^{39}$.

This study proposed to use accurate methods to verify food and nutritional aspects, so the major differentials were the use of a three-day food diary and direct weighing of the foods consumed. The main advantages of this method are collecting data as the foods were consumed, not depending 
on memory, and measuring the actual consumption, reducing errors. Furthermore, recording serving sizes when the meals are consumed reduces memory bias ${ }^{40}$.

The number of instruments to investigate the food intake of older people is limited, since most food intake assessment instruments rely on memory. Volkert et al ${ }^{41}$ claim that food intake assessment of older individuals requires special attention, especially in individuals with functional losses or health problems, such as cognitive deficits, which may compromise their ability to remember or record their food intake correctly. Given their impaired short-term memory, older people may easily forget the foods and beverages they consume, limiting the accuracy of memory-dependent food intake surveys. According to these authors, weighing foods is challenging, but it is the gold standard for assessing the food intake of older people.

The low accuracy of food intake assessments was minimized satisfactorily in this study, providing information that reflects the actual food intake well. It was not possible to assess the individual negative contribution of each oral problem to the nutritional status of the participants because of their low prevalence and the presence of more than one problem in some individuals.

It is known that factors as an older age, fragility, cognitive decline and general health, Parkinson's disease, food dependence, appetite reduction, among others, can be considered as risk factors for malnutrition ${ }^{42}$.

Although the degree of dependence and the fact that the mental state and depression signs had an influence on the nutritional status as previously shown ${ }^{15}$, these variables were not different among the groups or were not associated with energy consumption, corroborating the results of association of oral problems with food consumption.

Older people with oral problems presented lower food intake, which determined their nutritional status, but not lower micronutrient intake, probably because soft foods were offered to all participants, regardless of oral problems. Since the group's diet was already adapted, consisting of soft foods, we did not expect nutrient intakes to vary between the groups. However, the results show that there is dietary adaptation, since macronutrient intakes differed between the groups and was directly related to participant nutritional status. Another finding is that the presence of oral problems determined the preference for softer foods when options were available, such as for meats. This study reinforces the importance of good oral health for proper nutrition among older people. Special attention should be given to dependent older individuals, and strategies are needed to ensure that older people consume adequate amounts of quality foods whose consistencies are compatible with their cultural, social, and economic contexts.

\section{CONCLUSION}

Anthropometric indicators and the energy, protein and lipid intake were lower in elderly people with oral problems. This work warns about the importance of oral health for the good nutrition of older people and the need to establish strategies to adapt the diet of this population.

Acknowledgments: We thank the Long-Stay Institution located in the eastern region of São Paulo state, Brazil.

Funding source: This project was not sponsored.

Conflict of interests: The authors have no conflict of interests (personal, financial, or other).

\section{REFERENCES}

1. Ahmed T, Haboubi N. Assessment and management of nutrition in older people and its importance to health. Clin Interv Aging. 2010; 5: 207-216.

2. Martins $A B$, Santos $C M$, Hilgert JB, Marchi RJ, Hugo FN, Padilha DMP. Resilience and self-perceived oral health: $A$ hierarchical approach. J Am Geriatri Soc. 2011; 59: 725-731.

3. Huppertz VAL, Putten G-J van der, Halfens RJG, Schols IMGA, Groot LCPGM. Association between malnutrition and oral health in Dutch nursing home residents: Results of the LPZ Study. I Am Med Dir Assoc. 2017; 18: 948-954.

4. Okada K, Enoki H, Izawa S, Iguchi A, Kuzuya M. Association between masticatory performance and anthropometric measurements and nutritional status in the elderly. Geriatr Gerontol Int. 2010; 10: 56-63.

5. Dias-da-Costa JS, Galli R, Oliveira EA, Backes V, Vial EA, Canuto $R$, et al. Prevalence of poor self-rated mastication and associated factors in Brazilian elderly. Cad Saude Publica. 2010; 26: 79-88.

6. Iwasaki M, Taylor GW, Manz MC, Yoshihara A, Sato M, Muramatsu K, Watanabe $R$, Miyazaki H. Oral health status: relationship to nutrient and food intake among 80-year-old Japanese adults. Community Dent Oral Epidemiol. 2014; 42: 441-450.

7. Kossioni A, Bellou O. Eating habits in older people in Greece: The role of age, dental status and chewing difficulties. Arch Gerontol Geriat. 2011; 52: 197-201.

8. Andrade FB, Caldas Jr AF, Kitoko PM. Relationship between oral health, nutrient intake and nutritional status in a sample of Brazilian elderly people. Gerodontology. 2009; 26: 40-45.

9. Cousson PY, Bessadet M, Nicolas E, Veyrune IL, Lesourd B, Lassauzay C. Nutritional status, dietary intake and oral quality of life in elderly complete denture wearers. Gerodontology. 2012; 29: e685-e692.

10. Choi YK, Park DY, Kim Y. Relationship between prosthodontics status and nutritional intake in the elderly in Korea: National Health and Nutrition Examination Survey (NHANES IV). Int J Dent Hyg. 2014; 12: 285-290.

11. Hägglund $P$, Olai $L$, Ståhlnacke $K$, Persenius $M$, Hägg $M$, Andersson $M$, et al. Study protocol for the SOFIA project: Swallowing function, oral health, and food intake in old age: a descriptive study with a cluster randomized trial. BMC Geriatr. 2017; 17: 78.

12. Kamdem B, Seematter-Bagnoud L, Botrugno F, SantosEggimann B. Relationship between oral health and Fried's frailty criteria in community-dwelling older persons. BMC Geriatr. 2017; 17: 174.

13. Cochran WG. The estimation of sample size. In sampling techniques. 3rd edition. Edited by Cochran WG. New York: John Willey, 1977. p72-90.

14. Guigoz Y, Vellas BJ, Garry PJ. Mini nutritional assessment: a practical assessment tool for grading the nutritional state of elderly patients. Fact Res Gerontol. 1994; 4: 15-59. 
15. Avanutri Nutritional Assessment Software. Produced by Avanutri Informática Ltda., 2004, version 3.1.1, São Paulo.

16. Philippi ST, Latterza AR, Cruz ATR, Ribeiro, LC. Adapted food pyramid: A guide for a right food choice. Rev Nutr. 1999; 12: 65-80.

17. Lohman TG, Roche AF, Martorell R. Anthropometric standardization reference manual. Abridged edition. Campaign/USA: Human Kinetics Pub.; 1992.

18. Chumlea WC, Roche AF, Steinbaugh ML. Estimating stature from knee height for persons 60 to 90 years of age. J Am Geriatri Soc. 1985; 33: 116-120.

19. Folstein MF, Folstein SE, Mchugh PR. "Mini Mental State". A practical method for grading the cognitive state of patients for the clinician. J Psychiatri Res. 1975; 12: 189-198.

20. Katz S, Ford AB, Moskowitz RW et al. Studies of illness in the aged. The index of ADL: a standardized measure of biological and psychosocial function. JAMA. 1963; 21: 914-919.

21. Veras RP. Young country with white hair: the health of the older people in Brazil. Relume Dumará, Rio de Janeiro, 1994. p153

22. Ayres M, Ayres Jr M, Ayres DL, Santos AS. BioEstat 3.0: statistical applications in the fields of biological and medical sciences. Belém: Sociedade Civil Mamirauá; 2003.

23. Statistical Analysis Sistem - SAS, 2002. SAS Software: version 9.0. SAS Institute Inc., Cary, NC, USA.

24. Lipschitz DA. Screening for nutritional status in the elderly. Primary Care. 1994; 22: 55-67.

25. Rodrigues Junior HL, Scelza MFZ, Boaventura GT, Custodio $S M$, Moreira EAM, Oliveira DL. Relation between oral health and nutritional condition in the elderly. J Appl Oral Sci. 2012; 20: 38-44.

26. Rabito El, Vannucchi GB, Suen VMM, Castilho Neto LLC, Marchini JS. Weight and height prediction of immobilized patients. Rev Nutr. 2006; 19: 655-661.

27. Marcenes W, Steele JG, Sheiham A, Walls AWG. The relationship between dental status, food selection, nutrient intake, nutritional status, and body mass index in older people. Cad Saude Publica. 2003; 19: 809-816.

28. Alencar MA, Bruck NNS, Pereira BC, Câmara TMM, Almeida RDS: Profile of elderly living in a long-term care institution. Rev Bras Geriatr Gerontol. 2012; 15: 785-796.

29. Del Duca GF, Silva SG, Thumé E, Santos IS, Hallal PC. Institutionalization indicators for the older people: Case studies and controls. Rev Saude Publica. 2012; 46:147-153.

30. IBGE. Brazilian Institute of Geography and Statistics. Demographic Census 2010.

31. Emami E, Souza RF, Kabawat M, Feine JS. The Impact of edentulism on oral and general health. Int J Dent. 2013; 2013: 1-7.

32. Moynihan PJ. The relationship between nutrition and systemic and oral well-being in older people. J Am Dent Assoc. 2007; 138: 493-497.

33. Gibson BJ, Kettle JE, Robinson PG, Walls A, Warren L. Oral care as a life course project: A qualitative grounded theory study. Gerodontology. 2019; 36: 8-17.

34. Ástvaldsdóttir Á, Boström AM, Davidson T, Gabre P, Gahnberg $L$, Sandborgh Englund G, et al. Oral health and dental care of older persons-A systematic map of systematic reviews. Gerodontology. 2018; 35: 290-304.

35. Saintrain MVL, Saintrain SV, Sampaio EGM, Ferreira BSP, Nepomuceno TC, Frota MA, et al. Older adults' dependence in activities of daily living: Implications for oral health. Public Health Nurs. 2018; 35: 473-481.

36. Cabrini J, Fais LMG, Compagnoli MA, Mollo Junior FA, Pinelli, LAP. Wear time and the quality of the complete dentures $-A$ critical analysis. Cien Odontol Bras. 2008; 11: 78-85.

37. Muller F, Schimmel M. Tooth loss and dental prostheses in the oldest old. Eur Geriatr Med. 2010; 1: 239-243.

38. Mesas AE, Andrade SM, Cabrera MAS, Bueno VLRC. Oral health status and nutritional deficit in noninstitutionalized older adults in Londrina, Brazil. Rev Bras Epidemiol. 2010; 13: 434-445.

39. Galesi LF, Leandro-Merhi VA, Oliveira MRM. Association between indicators of dementia and nutritional status in institutionalized older people. Int J Older People Nurs 2012; 8: 236-243.

40. Fisberg RM, Marchioni DML, Colucci ACA. Assessment of food consumption and nutrient intake in clinical practice. Arq Bras Endocrinol Metabol 2009; 53: 617-624.

41. Volkert D, Schrader E. Dietary assessment methods for older persons: what is the best approach? Curr Opin Clin Nutr Metab Care 2013; 16: 534-540.

42. Fávaro-Moreira NC, Krausch-Hofmann S, Matthys C, Vereecken C, Vanhauwaert E, Declercq A, Bekkering GE, Duyck J. Risk Factors for Malnutrition in Older Adults: A Systematic Review of the Literature Based on Longitudinal Data. Adv Nutr 2016; 7: 507-522. 